\title{
Extract of the sea cucumber, Holothuria scabra, induces apoptosis in human glioblastoma cell lines
}

Kant Sangpairoj ${ }^{\mathrm{a}}$, Kulathida Chaithirayanon ${ }^{\mathrm{a}}$, Pornpun Vivithanaporn ${ }^{\mathrm{b}}$, Tanapan Siangcham ${ }^{\mathrm{c}}$, Prapaporn Jattujan ${ }^{\mathrm{a}}$, Tanate Poomtong ${ }^{\mathrm{d}}$, Saksit Nobsathian ${ }^{\mathrm{e}}$, Prasert Sobhon ${ }^{\mathrm{a}, \mathrm{c}^{*}}$

a Department of Anatomy, Faculty of Science, Mahidol University, Rama VI Rd, Ratchathewi, Bangkok 10400, Thailand; 'bepartment of Pharmacology, Faculty of Science, Mahidol University, Rama VI Rd, Ratchathewi, Bangkok 10400, Thailand; ${ }^{c}$ Faculty of Allied Health Sciences, Burapha University, Long-Hard Bangsaen Road, Mueang District, Chonburi 20131, Thailand; ${ }^{\mathrm{d}}$ Coastal Fisheries Research and Development Center, Klongwan, Prachuabkirikhan 77000, Thailand; ${ }^{\mathrm{e}}$ Mahidol University, Nakhonsawan Campus, Nakhonsawan 60130, Thailand

*Corresponding author: Prof. Prasert Sobhon, Faculty of Allied Health Sciences, Burapha University, and Department of Anatomy, Faculty of Science, Mahidol University, Thailand

Submission Date: May 16, 2016, Accepted Date: July 27, 2016, Publication Date: July 30, 2016

\begin{abstract}
Background: Glioblastoma is the most aggressive primary brain tumor resistant to conventional treatment, and has a frequent recurrence. Holothuria scabra is the most widely consumed sea cucumber in Thailand and Asian countries. Sea cucumber extracts have valuable bioactive ingredients that are utilized in Chinese traditional medicine for several therapeutic measures including anti-cancer. In this study, we aimed to test the anticancer activity of $H$. scabra body wall extract in ethyl acetate fraction against two human glioblastoma cell lines A172 and U87MG.
\end{abstract}

Material and methods: The anticancer effect of the ethyl acetate fraction of body wall extracts from $H$. scabra (HSBWEA) was tested against two human glioblastoma cell lines A172 and U87MG to determine cell viability, apoptotic cell analysis, mitochondrial membrane potentials, nuclear condensation and expression of apoptotic molecules. The bioactive compound in the extract was characterized by LC-MS/MS.

Results: The extract exhibited strong cytotoxic effect to A172 and U87MG cells with IC50 4.23 and $4.46 \mu \mathrm{g} / \mathrm{ml}$, respectively. The extract also induced both early and late stages of apoptosis, loss of mitochondrial membrane potentials and nuclear condensation and fragmentation. After treatment with the extract for $24 \mathrm{~h}$, the cells expressed increasing amounts of a pro-apoptotic Bax and caspase- 3 while an anti-apoptotic Bcl-2 was decreased in a concentration-dependent manner. The major bioactive components in this extract are triterpene glycosides similar to those described previously in $H$. scabra as well as in other related sea cucumber species.

Conclusion: The crude extract from the body wall of $H$. scabra exhibited anticancer activity against human glioblastoma cells through the mitochondrial-mediated apoptotic pathway, and the compounds in the extract might be a novel candidate for anti-glioblastoma.

Keywords: Sea cucumber, Holothuria scabra, Glioblastoma, Triterpene glycoside, Apoptosis 


\section{BACKGROUND}

Glioblastoma (GBM) is the most common malignant astrocytic brain tumor that accounts for approximately $60 \%$ of all malignant brain tumors in adults [1]. This type of tumor is characterized by highly aggressive proliferation and diffuse invasion with extensive development of microvessels in the cancerous tissue. As GBM enlarges and spreads within intracranium, these patients have a poor prognosis and increased mortality rate especially after incomplete surgical resection. Furthermore, resistance against anti-neoplastic drug and limited blood-brain barrier permeability reduce the chemotherapeutic efficacy against GBM treatment [2]

Nowadays, bioactive ingredients from natural sources have been increasingly used for chemotherapy against GBM. The sea cucumber Holothuria scabra (sandfish) is an important tropical sea cucumber species that widely distributed in natural habitat as well as being cultured in South-East Asia, South Pacific, and India [3]. It has long been utilized as functional foods and traditional medicines in Chinese and Malaysian literatures for treatment of many diseases including several types of cancer [4]. Anticancer effects of a few species of sea cucumbers have been investigated using crude extracts as well as semi-purified bioactive compounds. Several types of compounds have been identified in sea cucumber including triterpene glycosides, sulfated polysaccharides, chondroitin sulfates and glycosaminoglycans $[4,5]$. Triterpene glycosides, which are abundantly produced as secondary metabolites, have been shown to be the most potent anticancer compounds. These compounds were found in their body wall, cuvierian tubules and viscera of the sea cucumbers, and they are actually the main poisonous substance being produced and released for defensive purpose against predators and pathogens $[6,7]$. Anti-proliferative, cytotoxic, and apoptotic inducing effects of sea cucumber extracts containing triterpene glycosides against various cancer cells have been reported, including lung, pancreatic, hepatocellular, and breast cancers [5, 8, 9]. Purified triterpene glycosides in $H$. scabra has been isolated and tested for antineoplastic activity against KB (human epidermoid), HepG2, BEL-7402 (human hepatoma), HL-60, MOLT-4 (human leukemia), and A549 (human lung) tumor cell lines [10, 11]. H. scabra triterpene glycosides caused apoptosis in HepG2 cells by decreasing mitochondrial transmembrane potentials and increasing pro-apoptotic Bax as well as Caspase-3, -8, and -9 expressions [12]. Triterpene glycosides isolated from other holothurian sea cucumbers including $H$. fuscocinerea, H. moebii, and $H$. axiloga have been tested against various human GBM cells (U251 and U87MG) and showed inhibition of cell proliferation as well as promoting cytotoxicity $[13,14]$. Triterpene glycosides from H. moebii also induced apoptosis as well as reduced metabolic regulators of glycolysis and glutaminolysis against U87MG cells, resulting in the suppression of tumor cell proliferation [13]. However, the effects of H. scabra extracts against GBM have not yet been reported, and the molecular mechanism in causing apoptotic cell death has not yet been elucidated. Therefore, this study aimed to identify the bioactive components in the ethyl acetate solvent extracts from body wall of $H$. scabra (HSBWEA) and their in vitro effect for apoptosis on human GBM cells at both cellular and molecular levels.

\section{METHODS}

\section{Extraction of $\boldsymbol{H}$. scabra in ethyl acetate fraction}

Adult H. scabra were obtained from the Coastal Fishery Research and Development Center, Prachuap Khiri Khan Province, Thailand. Their body walls were separated from other body parts then minced into small pieces about $1 \mathrm{~cm}^{2}$, freeze-dried, and extracted using acetone (1 1: $100 \mathrm{~g}$ samples) to denature cellular proteins and liberate secondary metabolites. The 
supernatant was extracted further with methanol. The extract was then evaporated in a rotary evaporator at $-40^{\circ} \mathrm{C}$. The dried extract was redissolved in $10 \%$ methanol in water and then fractionated by $n$-hexane and ethyl acetate using separating funnels. The ethyl acetate fraction was collected for further studies.

\section{Cell culture}

A172 and U87MG human glioblastoma cell lines were obtained from American Type Culture Collection (ATCC, USA). U87MG cells were cultured in MEM supplemented with 10\% (v/v) fetal bovine serum, 1\% penicillin/streptomycin and 1\% sodium pyruvate. A172 cells were cultured in DMEM supplemented with $10 \%(\mathrm{v} / \mathrm{v})$ fetal bovine serum and $1 \%$ penicillin/streptomycin. Human fetal astrocytes (HFAs), kindly provided by Dr. Pornpun Vivithanaporn (Mahidol University, Thailand), were cultured in MEM supplemented with $10 \%(\mathrm{v} / \mathrm{v})$ fetal bovine serum and 1\% penicillin/streptomycin. Cells were incubated under humidified atmosphere of $5 \% \mathrm{CO}_{2}$ at $37^{\circ} \mathrm{C}$.

\section{Treatment of cell lines with the extract and cytotoxicity analysis}

A172, U87MG and HFA cells were seeded into 96-well plate and then treated with various concentrations of HSBWEA extracts diluted in serum-free media for $24 \mathrm{~h}$. Thereafter, MTT (Sigma, USA) was added into the media of each well at a final concentration of $30 \mu \mathrm{g} / \mathrm{ml}$, followed by $3 \mathrm{~h}$ incubation. Cytotoxicity was measured by spectrophotometer at the absorbances of 562 and $630 \mathrm{~nm}$ (Flow Laboratories, VA, USA).

\section{Analysis of apoptotic cells by flow cytometry}

Different apoptotic stages of the treated cells were analyzed using Annexin VFITC/propridium iodide apoptosis kit (Becton Dickinson, USA). After $24 \mathrm{~h}$ treatment at various concentrations of HSBWEA, cells were harvested, and $1 \times 10^{5}$ cells were incubated with annexin V-FITC and PI in the binding buffer. Apoptotic cells were evaluated by FACScanto flow cytometer (Becton Dickinson, USA).

\section{Analysis of apoptosis by determining nuclear condensation}

The nuclear condensation indicative of apoptosis was demonstrated by Hoechst 33342 nuclear staining (Sigma, USA). After treatment with the extract, cells were fixed with 4\% paraformaldehyde and incubated with 5\% normal goat serum diluted in $0.01 \mathrm{M}$ PBS. Cells were incubated with $30 \mu \mathrm{g} / \mathrm{ml}$ Hoechst33342 nuclear staining and visualized by Olympus BX53 fluorescence microscope (Olympus, Japan) at $480 \mathrm{~nm}$.

\section{Detection of mitochondrial membrane potential}

Disruption of mitochondrial membrane potentials $(\Delta \Psi \mathrm{m})$ is a marker indicating the early stage of apoptosis. The $\Delta \Psi \mathrm{m}$ after HSBWEA treatment was detected by DePsipher ${ }^{\mathrm{TM}}$ kit (Trevigen, USA) containing a lipophilic cationic fluorescent dye acting as a mitochondrial activity marker, according to manufacturer's guideline. Briefly, media of the treated cells on plate were removed and the cells were further incubated in $5 \mu \mathrm{g} / \mathrm{ml}$ of DePsipher solution at $37^{\circ} \mathrm{C}$ for $15 \mathrm{~min}$. Then the live cells were observed by Olympus IX83 fluorescence microscope (Olympus, Japan) using fluorescein $(510 / 527 \mathrm{~nm})$ and rhodamine $(585 / 590 \mathrm{~nm})$ filters. The dye is readily penetrated normal cells and appeared as red fluorescence in healthy 
mitochondria. In apoptotic cells, the dye was unable to access the transmembrane space of the collapsed mitochondria and remained in cytoplasm as a green fluorescence.

\section{Immunoblotting}

Whole cellular proteins after treatment with the extract were prepared using RIPA cell lysis buffer (Cell Signaling Technology, USA). Protein concentrations were determined by Lowry protein assays (Bio-rad, USA). Equivalent amount of total proteins $(30 \mu \mathrm{g})$ were separated by $15 \%$ SDS-PAGE and then transferred onto nitrocellulose membranes. The membranes were blocked with Tris-Buffered Saline containing Tween-20 (TBST) and 5\% BSA for $1 \mathrm{~h}$ then incubated in primary antibodies at $4{ }^{\circ} \mathrm{C}$ overnight. The primary antibodies included rabbit anti-Bax, rabbit anti-Bcl-2 (Cell Signaling Technology, USA), rabbit anti-pro and active caspase-3 (diluted at 1:700) (Abcam, USA) and rabbit anti- $\beta$-actin (diluted at 1:200) (Santa Cruz, USA) diluted in 0.01M TBST with 5\% BSA. The membranes were washed with TBST then incubated with corresponding horseradish peroxidase (HRP)-conjugated secondary antibody (Southern Biotech, Birmingham, USA) diluted in 0.01M TBST at 1:5000 at room temperature for $1 \mathrm{~h}$. Specific targeted proteins were visualized by ECL chemiluminescence system (Thermo Fisher Scientific Inc., USA).

\section{Characterization of compounds in the crude extract}

The LC-MS/MS was used to identify compounds in the ethyl acetate extract. HPLC was performed in an Agilent 1100 series pump with autosampler, and vacuum degasser (Agilent, Palo, Alto, CA). The separation was performed by using a fused core C18-column (Walter, Milford, MA) with an APCI source in the positive ion mode. The mobile phase consisted of acetonitrile and $0.1 \%$ formic acid at the flow rate of $1 \mathrm{ml} / \mathrm{min}$. The gradient was increased from 30 to $60 \%$ within 36 min.

The MS analyses were performed by IONIC 3Q Series 200 molecular analyzer. The separated fractions were applied to a mass spectrometer by direct injection with $20 \mu \mathrm{l} / \mathrm{min}$ of flow rate. The ionization was performed by electrospray mode (ESI).

\section{Statistical analysis}

Data were expressed as mean \pm SEM. Statistical variations of all experiments were analyzed by GraphPad Prism statistical analysis software (GraphPad Software Inc, USA) using oneway ANOVA test. A p-value less than 0.05 was considered statistically significant.

\section{RESULTS}

\section{HSBWEA induced cytotoxicity in human glioblastoma cells}

After treatment with HSBWEA for $24 \mathrm{~h}$, viabilities of A172 and U87MG cells were significantly decreased in a concentration-dependent manner from 1 to $100 \mu \mathrm{g} / \mathrm{ml}$ compared with DMSO-treated control group (Fig. 1A). At $24 \mathrm{~h}$, the 50\% inhibitory concentration $\left(\mathrm{IC}_{50}\right)$ of HSBWEA for A172 and U87MG cells were 4.46 and $4.23 \mu \mathrm{g} / \mathrm{ml}$, respectively. Furthermore, HSBWEA exhibited greater cytotoxicity than temozolomide (TMZ), a commonly used anti-GBM drug, on both cell lines at the same concentrations (Fig. 1B). By contrast, HSBWEA not exhibited toxicity in primary human fetal astrocytes (HFAs) from 0.1 $-5 \mu \mathrm{g} / \mathrm{ml}$, but their viability was constantly decreased to about $20 \%$ after being treatment at $10-100 \mu \mathrm{g} / \mathrm{ml}$ (Fig. 1C). 

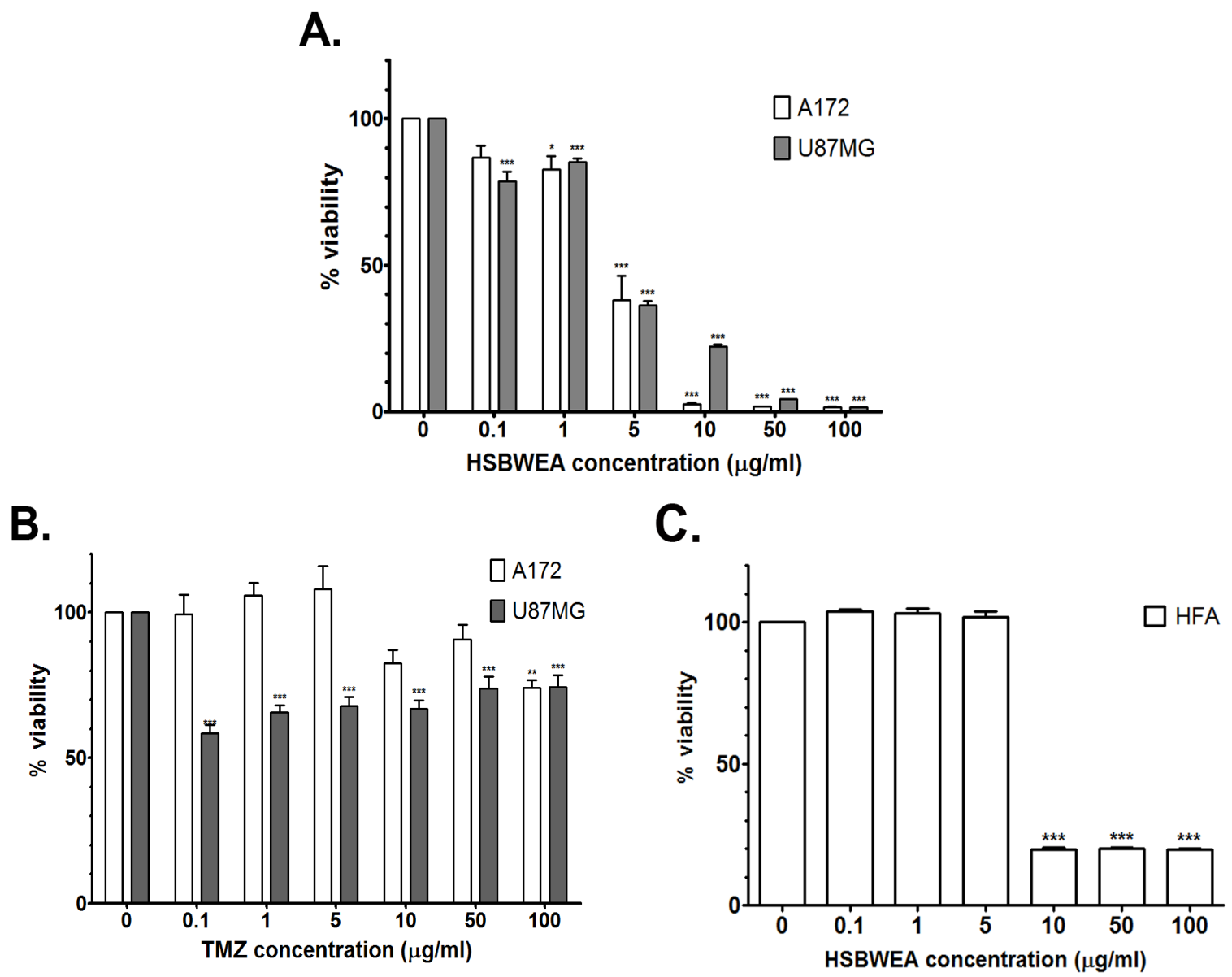

Figure 1. Cell viability of A172 and U87MG glioblastoma cell lines after treatment with HSBWEA at various concentrations (w/v) for $24 \mathrm{~h}$, compared with TMZ. (A) Cell viability after HSBWEA treatment. (B) GBM cell viability after TMZ treatment at the same concentration. (C) Viability of HFA cells after HSBWEA treatment. ${ }^{*} p<0.05,{ }^{*} p<0.01$, $* * * p<0.001$.

\section{HSBWEA induced glioblastoma cell apoptosis with characteristic morphological changes}

The effect of HSBWEA on apoptosis of human glioblastoma cells was analyzed by flow cytometry using Annexin V and PI double stainings. HSBWEA caused a significant increase of apoptosis on A172 cells (Fig. 2A). The percentages of early and late apoptotic cells were generally increased after HSBWEA treatment at 1,5 , and $10 \mu \mathrm{g} / \mathrm{ml}$ with relatively higher proportion of late apoptosis at the last two concentrations (Fig. 2B). Induction of cellular apoptosis was also detected in U87MG cells but with lower percentage of apoptotic cells than A172 (data not shown).

Major morphological changes indicative of apoptosis were observed including the shortening of the cell processes, the detachment and loss of confluence, resulting in the round-up of cells and cytoplasmic condensation, and formation of apoptotic bodies, which are concentration-dependent (Fig. $3 \mathrm{C}, \mathrm{G}, \mathrm{K}, \mathrm{O} ; 4 \mathrm{C}, \mathrm{G}, \mathrm{K}, \mathrm{O}$ ). This result suggested that HSBWEA could induce apoptosis in GBM cells in a concentration-dependent manner. 


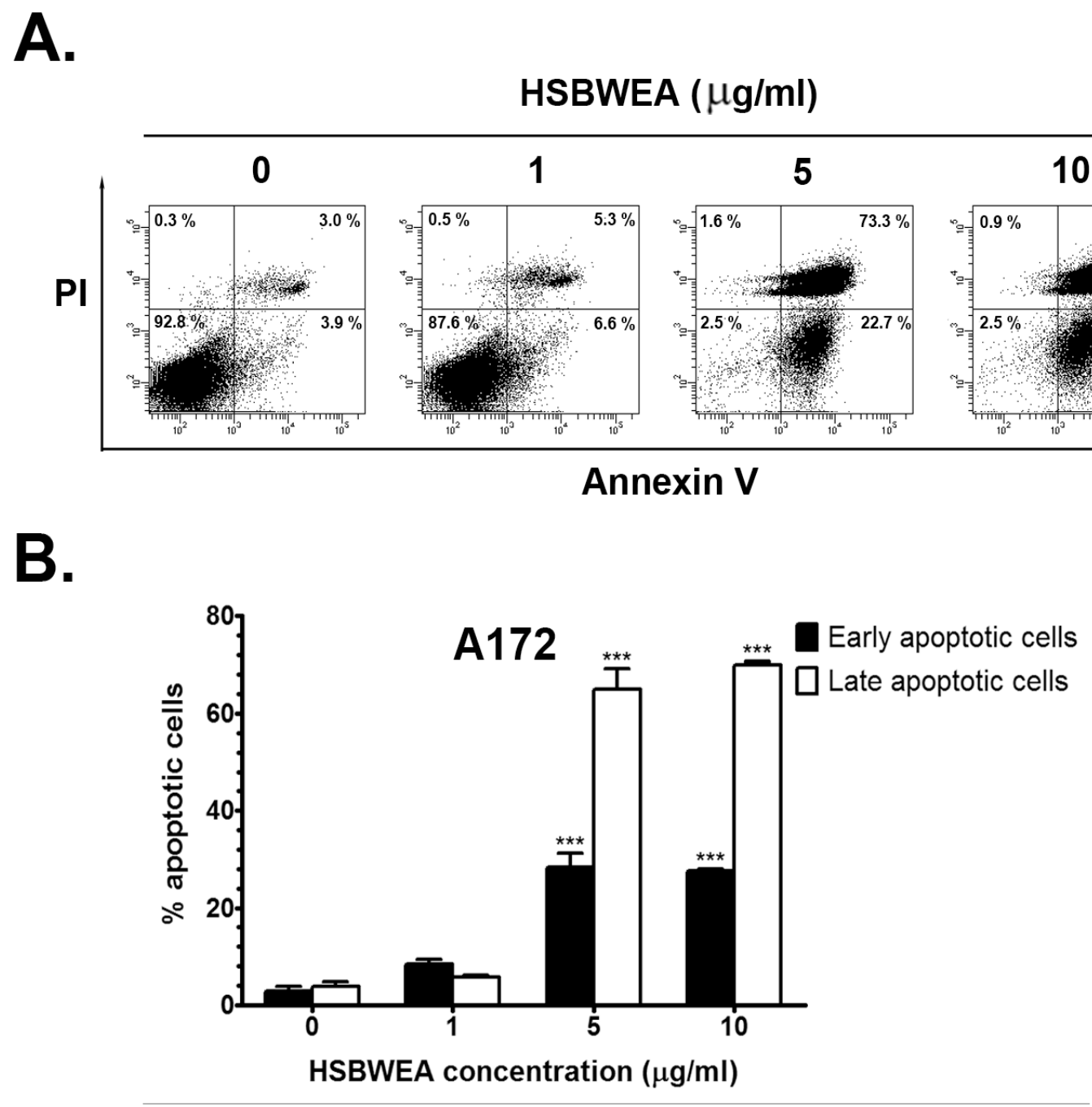

Figure 2. Analysis of apoptotic cells following HSBWEA treatment. (A) Analysis of apoptotic A172 cells after HSBWEA treatments for $24 \mathrm{~h}$ by Annexin V/PI double staining and flow cytometry, (B) The percentage of apoptotic cells at the early and late stages per total cells. $* * * p<0.001$.

\section{HSBWEA promoted loss of mitochondrial membrane potentials}

The loss of mitochondrial transmembrane potentials $(\Delta \Psi \mathrm{m})$ indicates one of the early intracellular changes following the initiation of apoptosis. The effect of HSBWEA on the $\Delta \Psi \mathrm{m}$ of human GBM cells was examined using DePsipher dye. In normal cells, the dye aggregates on polarized membrane forming a red fluorescence. In apoptotic cells, the dye was unable to access the mitochondrial membrane and remaining in the cytoplasm as monomeric form which exhibits a green fluorescence. HSBWEA treated cells exhibited an increased level of green fluorescence against low red fluorescence (Fig. 3 E, F, I, J, M, N; Fig, 4 E, F, I, $\mathrm{J}, \mathrm{M}, \mathrm{N}$ ), as compared to untreated cells which showed intense red fluorescence with much less intense green fluorescence (Fig. 3 A, B; Fig. 4 A, B). The increase of green fluorescence intensity after HSBWEA treatment was concentration dependent in both cell lines. 


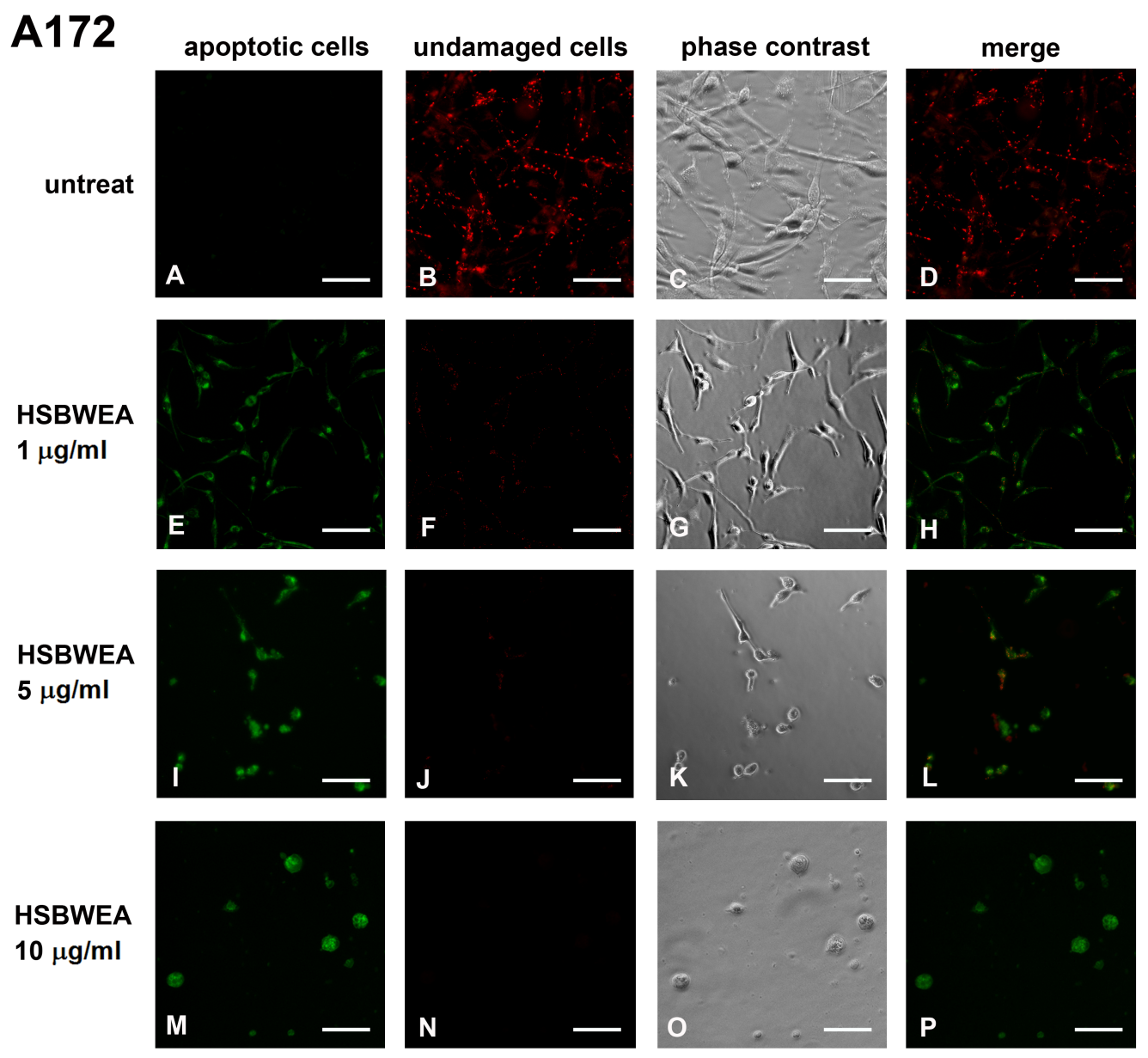

A172

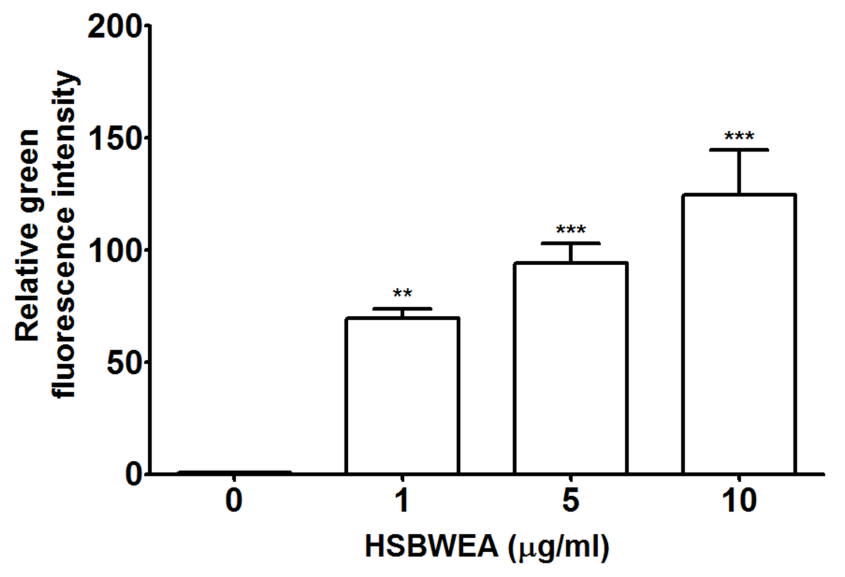

Figure 3. Changes of mitochondrial membrane potentials in A172 cells after exposure to HSBWEA at 1,5 and $10 \mu \mathrm{g} / \mathrm{ml}$ for $24 \mathrm{~h}$, as observed by live cell fluorescence microscope. The relative intensity of green fluorescence to determine the level of mitochondrial-damaged apoptotic cells was represented in the bar graph. (A, E, I, M) The green fluorescence indicates mitochondrial-damaged apoptotic cells. (B, F, J, N) The aggregated red fluorescence indicates undamaged cells. (C, G, K, O) The phase contrast images reveal morphological changes. (D, H, L, P) The pictures of green and red fluorescences were merged. Scale bar $=50 \mu \mathrm{m}$. $* * * p<0.001$. 


\section{U87MG}
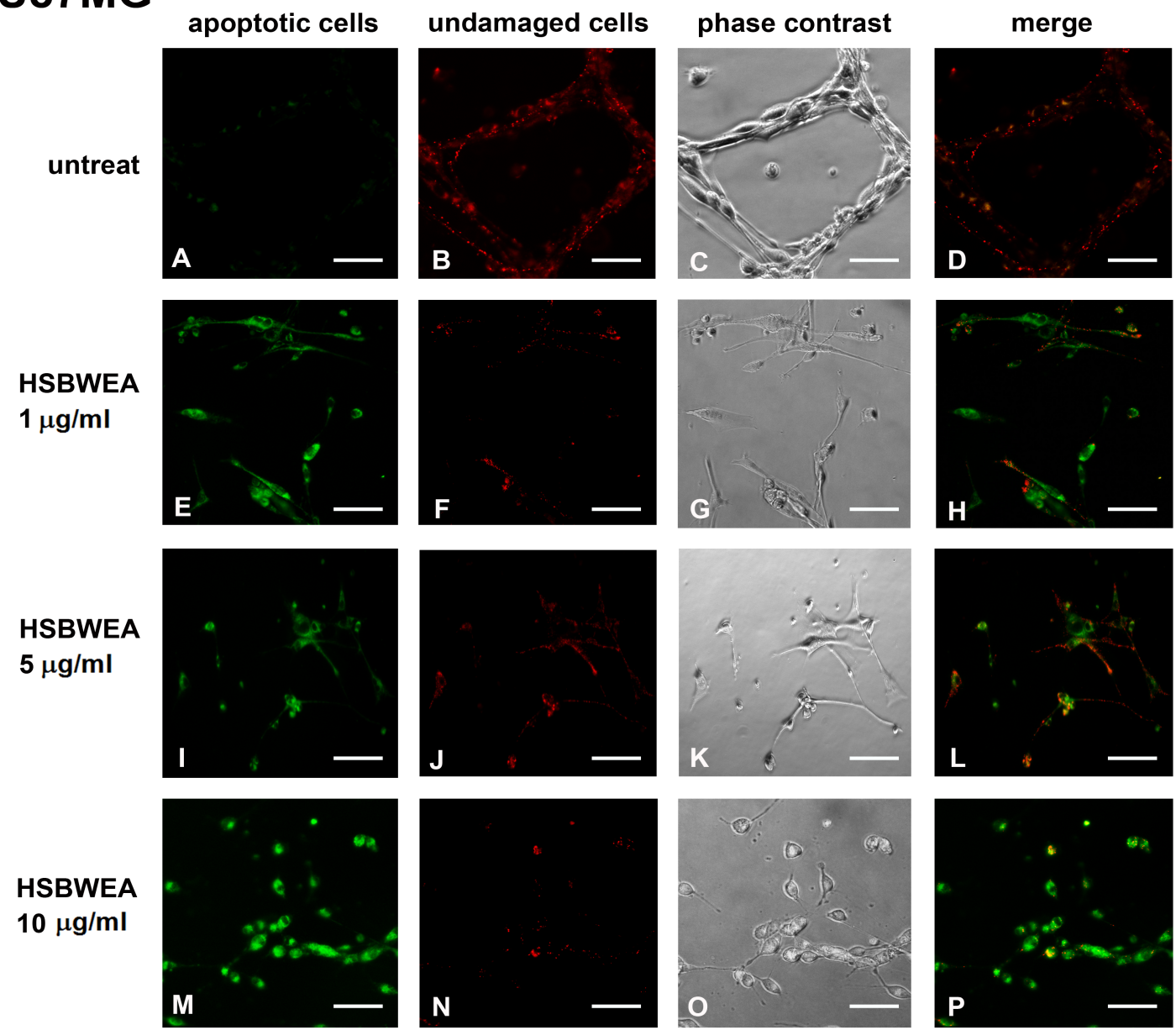

U87MG

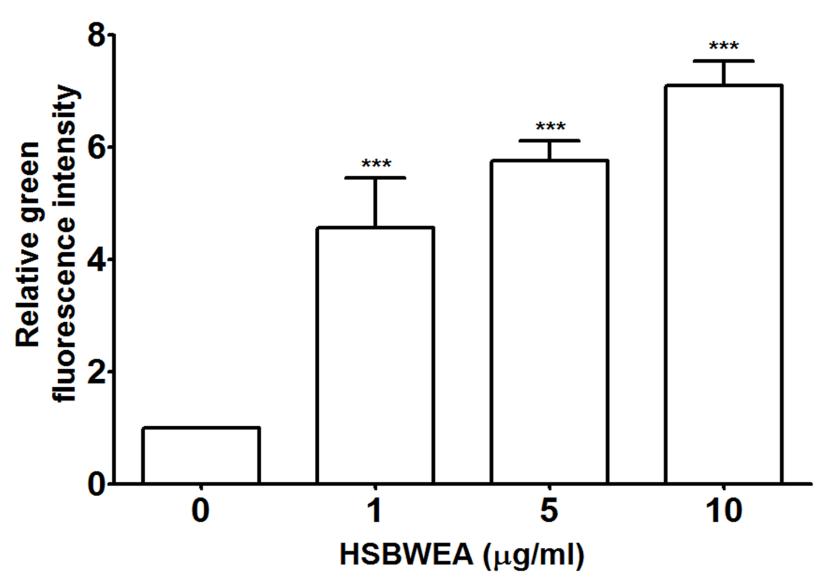

Figure 4. Changes of mitochondrial membrane potentials in U87MG cells after exposure to HSBWEA at 1,5 and $10 \mu \mathrm{g} / \mathrm{ml}$ for $24 \mathrm{~h}$, as observed by live cell fluorescence microscope. The relative intensity of green fluorescence to determine the level of mitochondrial-damaged apoptotic cells was represented in the bar graph. (A, E, I, M) The green fluorescence indicates mitochondrial-damaged apoptotic cells. (B, F, J, N) The aggregated red fluorescence indicates undamaged cells. $(\mathrm{C}, \mathrm{G}, \mathrm{K}, \mathrm{O})$ The phase contrast images reveal morphological changes. (D, H, L, P) The pictures of green and red fluorescences were merged. Scale bar $=50 \mu \mathrm{m} . * * * p<0.001$. 


\section{HSBWEA induces nuclear condensation and fragmentation}

After HSBWEA treatment, apoptosis could be validated by morphological damages in the nucleus stained with Hoechst33342. Nuclear damages were observed following HSBWEA exposure at the doses 1 and $10 \mu \mathrm{g} / \mathrm{ml}$ for $24 \mathrm{~h}$ as representative concentrations. Apoptotic nuclei exhibited volume reduction, irregular condensation of chromatin, and nuclear fragmentation. which were observed in both cell lines in a concentration-dependent manner (Fig. 5). This result confirmed that HSBWEA could induce apoptosis in both GBM cell lines.

HSBWEA $(\mu \mathrm{g} / \mathrm{ml})$

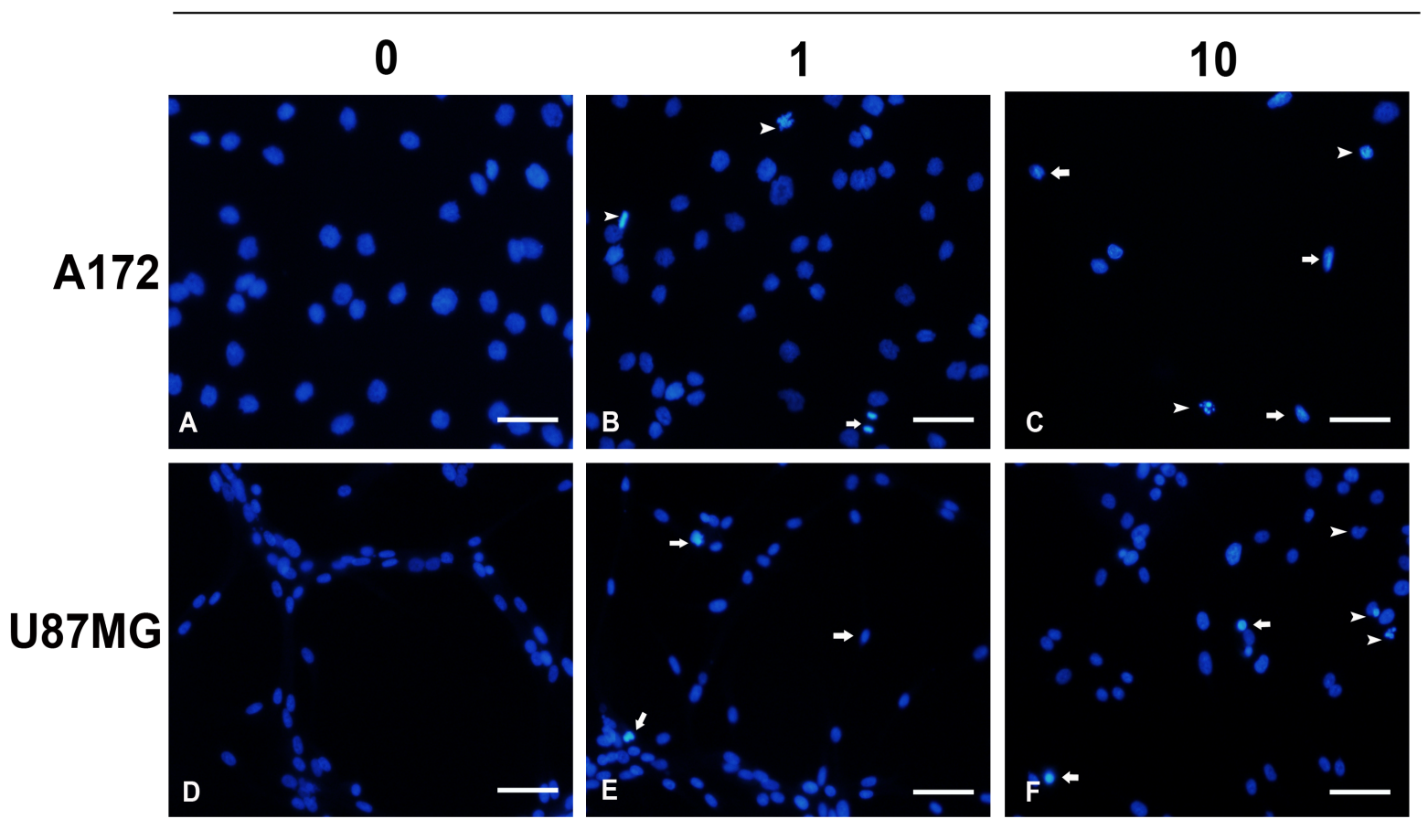

Figure 5. Detection of nuclear damages in U87MG (A-C) and A172 cells (D-F) following HSBWEA treatment at 1 and $10 \mu \mathrm{g} / \mathrm{ml}$ for $24 \mathrm{~h}$ by Hoechst33342 staining, as observed by fluorescence microscope. Arrow indicates chromatin condensation. Arrowhead indicates nuclear fragmentation. Scale bar $=50 \mu \mathrm{m}$.

\section{HSBWEA enhances expressions of apoptosis-related molecules}

Effects of HSBWEA in activating apoptosis in GBM cells were also observed at molecular level. Differential expressions of the pro- and anti-apoptotic proteins in A172 and U87MG cells after HSBWEA exposure for $24 \mathrm{~h}$ were detected (Fig. 6, 7). After treatment with 1, 5, and $10 \mu \mathrm{g} / \mathrm{ml}$ of HSBWEA, the relative expression level of Bax protein, a pro-apoptotic marker, was significantly increased in a concentration-dependent manner (Fig. 6B, 7B), whereas Bcl-2 expression, an anti-apoptotic marker, was decreased (Fig. 6C, 7C). The ratio between Bax and Bcl-2 was also significantly increased in both cell lines following the treatment (Fig. 6D, 7D). In addition, the relative expression level of active to inactive forms of caspase- 3 was significantly increased after the treatment at the same concentration in both cell lines (Fig. 6E\&F; 7E\&F). 
A.

A172

\begin{tabular}{|c|}
\hline HSBWEA $(\mu \mathrm{g} / \mathrm{ml})$ \\
\hline 0 \\
\hline
\end{tabular}

Bax

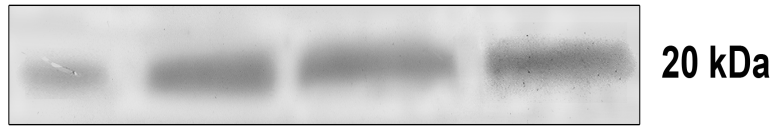

Bcl-2

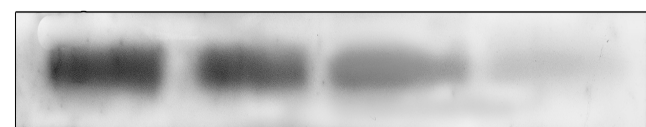

$24 \mathrm{kDa}$

pro-caspase-3

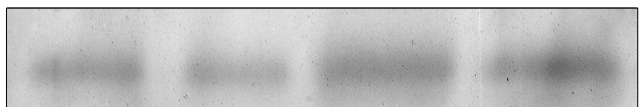

$32 \mathrm{kDa}$

cleaved caspase-3

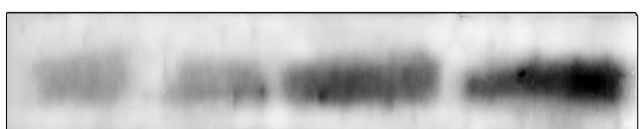

$17 \mathrm{kDa}$

$\beta$-actin

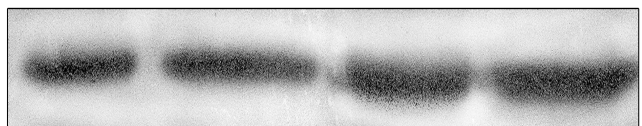

\section{$43 \mathrm{kDa}$}

B.

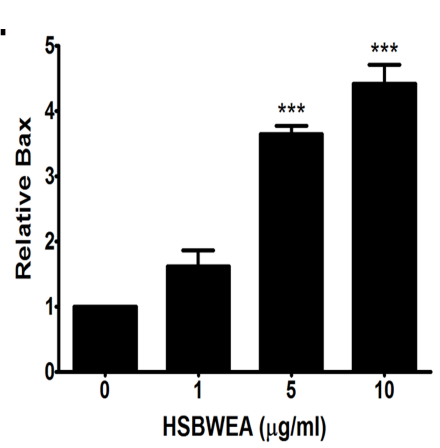

C.

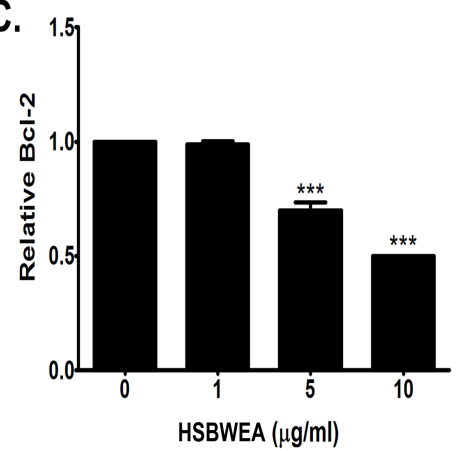

D.

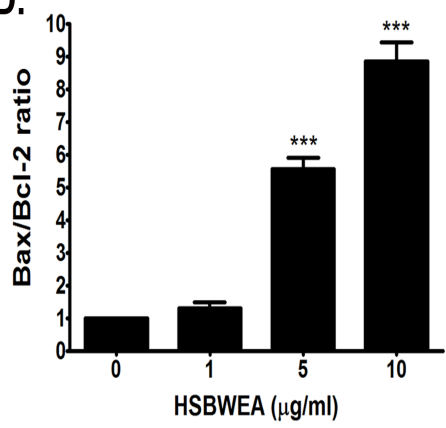

E.
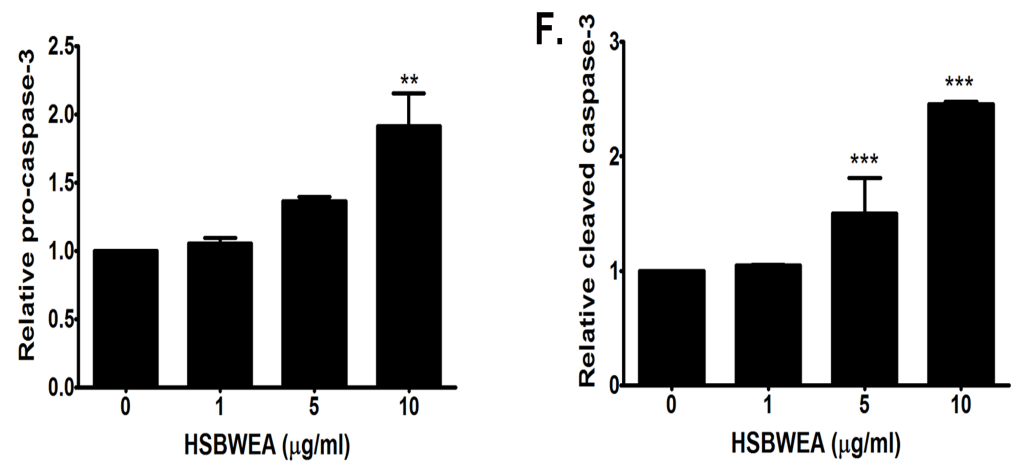

Figure 6. Analysis of apoptotic proteins expression in A172 cells after HSBWEA treatment at 1,5 and $10 \mu \mathrm{g} / \mathrm{ml}$ for $24 \mathrm{~h}$. (A) Immunoblotting analysis of Bax, Bcl-2, pro-caspase-3 and cleaved caspase- 3 protein expressions. The protein level was normalized with $\beta$-actin. Relative expression levels of (B) Bax, (C) Bcl-2, (D) The ratio of Bax and Bcl-2, (E) procaspase-3, and (F) cleaved-caspase-3 were analyzed and compared with untreated group. ${ }^{*} p$ $<0.05, * * p<0.01, * * * p<0.001$. 
A.

U87MG
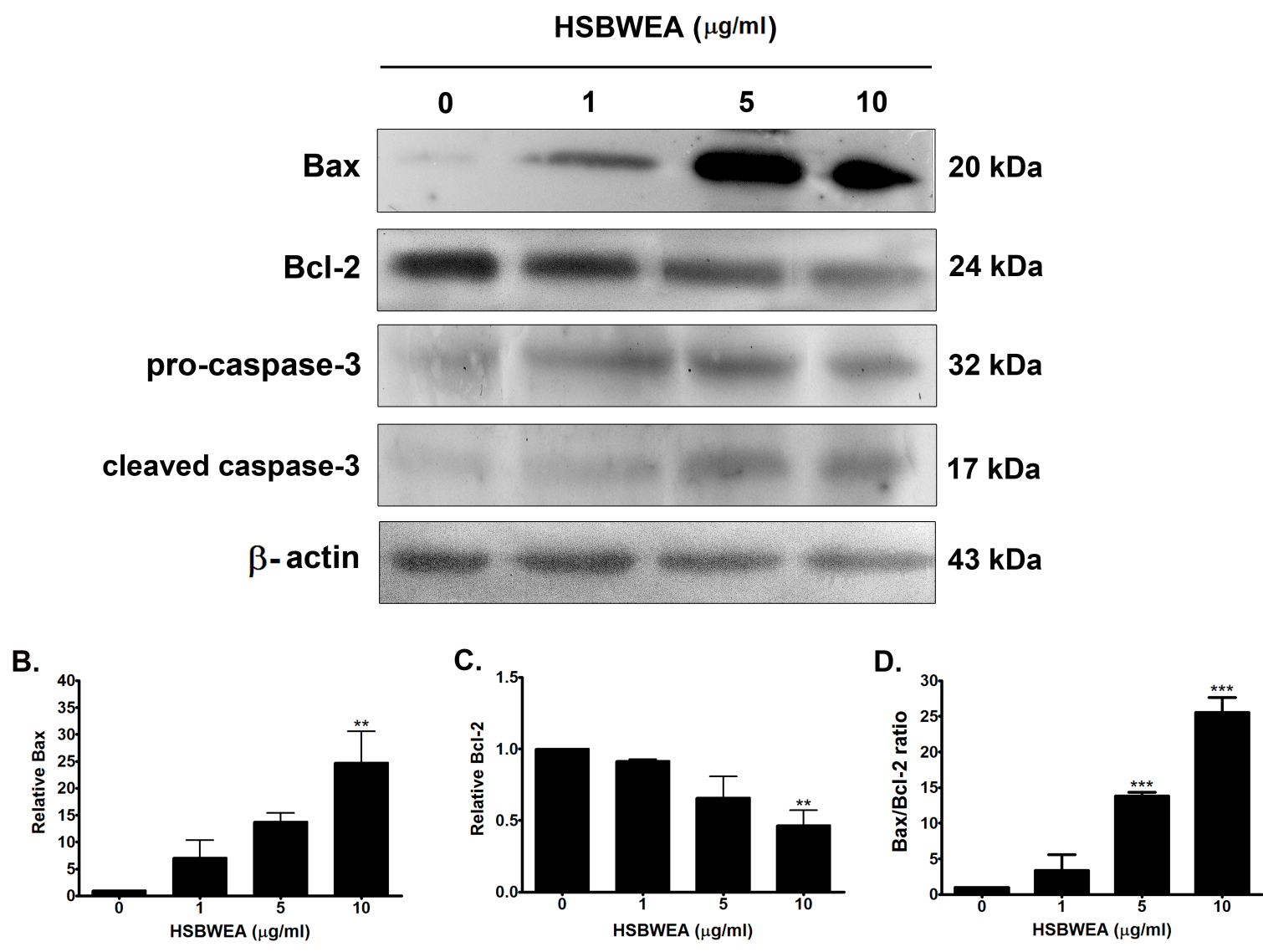

E.

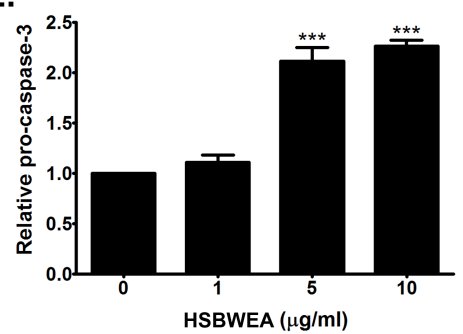

F.

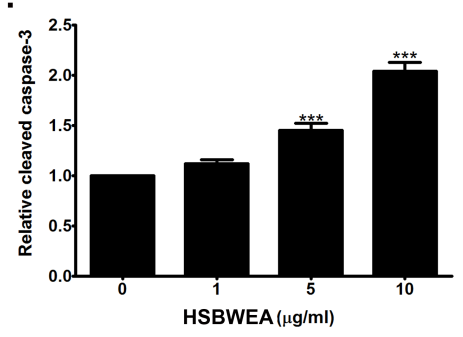

Figure 7. Analysis of apoptotic proteins expression in U87MG cells after HSBWEA treatment at 1,5 and $10 \mu \mathrm{g} / \mathrm{ml}$ for $24 \mathrm{~h}$. (A) Immunoblotting analysis of Bax, Bcl-2, procaspase-3 and cleaved caspase-3 protein expressions. The protein level was normalized with $\beta$-actin. Relative expression levels of (B) Bax, (C) Bcl-2, (D) The ratio of Bax and Bcl-2, (E) pro-caspase-3, and (F) cleaved-caspase-3 were analyzed and compared with untreated group. $* p<0.05, * * p<0.01, * * * p<0.001$.

\section{Characterization of bioactive compounds in HSBWEA}

In order to characterize the main bioactive compounds in the extract, LC-MS/MS was performed. Data of mass spectra obtained from the LC- MS/MS was characterized and compared with published data of identified bioactive compounds of related holothurian sea cucumbers $[10,11,15-20]$. The separation of HSBWEA extracts by HPLC showed the major peak of compound at the retention time of 19.013 min (Fig. 8A), which was selected for further identification. 
By LC-MS/MS., the mass spectra exhibited 5 major peaks of $m / z 507,764,1014,1227$ and 1522 with 4 minor peaks of $m / z$ 1243, 1259, 1302 and 1392 (Fig. 8B). Nine mass spectra were detected that corresponded with several known triterpene glycosides in holothurian and other related sea cucumbers. Fragmentation patterns of the compound at $\mathrm{m} / \mathrm{z} 1227$ and 1243 were shown in Fig. 9A\&B and the characterized compounds in table 1. These data indicated that this unpurified HSBWEA extract had a variety of compounds corresponding to several purified triterpene glycosides that had been characterized in other holothurians. The $\mathrm{m} / z 507$ displayed the most intense signal representing the sodiated oligosaccharide residues as one of the key diagnostic ions of the holothurian triterpene glycosides [15]. Markedly high intensity was observed at $\mathrm{m} / \mathrm{z} 764,1014,1227$, and 1522 while lower intensity was observed at $\mathrm{m} / \mathrm{z}$ $1243,1259,1302$, and 1392. Interestingly, these compounds resembled scabraside A and B in the ethanolic extract, and holothurin A3 triterpene glycosides in the methanolic extract isolated from dried H. scabra at $m / z$ 1227, 1243 and 1259, respectively [10, 11]. The extract also contained compounds that corresponded to triterpene glycosides from H. forskali, $H$. lesson, Athyonidium chilensis and Apostichopus japonicas [15-20]. Thus, the result demonstrated that complex triterpene glycosides were the main bioactive components in the HSBWEA.
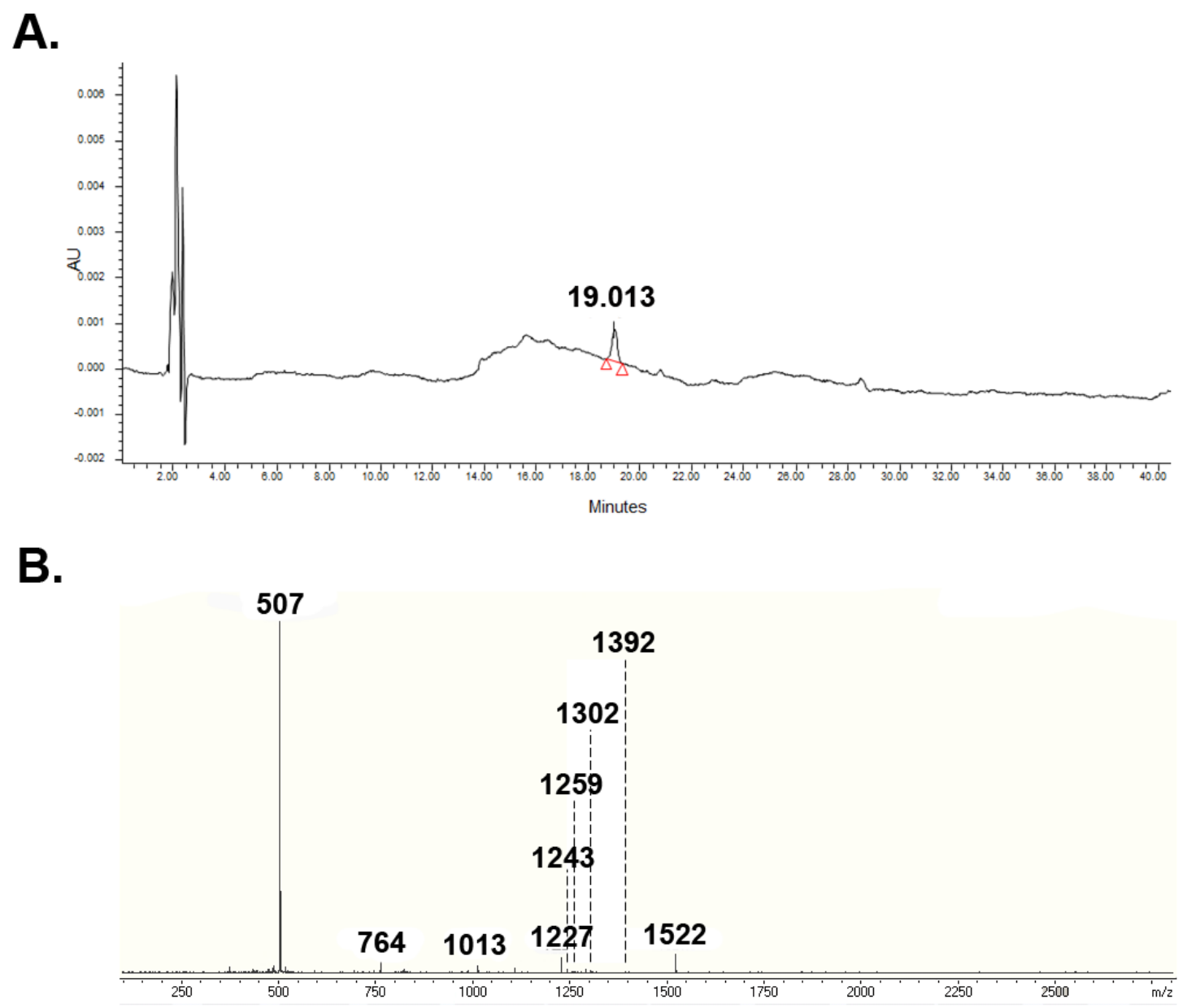

Figure 8. Characterization of bioactive compounds in HSBWEA extract. (A) Chromatogram of HSBWEA exhibited a major peak at the retention time $19.014 \mathrm{~min}$. (B) The average mass spectra from fraction 19 analyzed by LC-MS/MS. 
A.

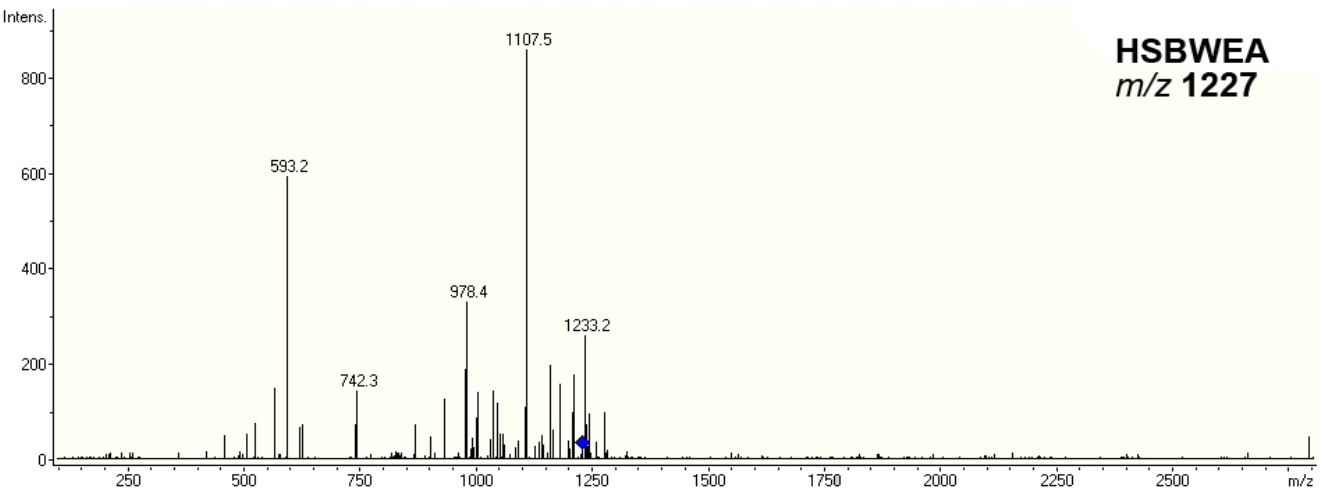

B.

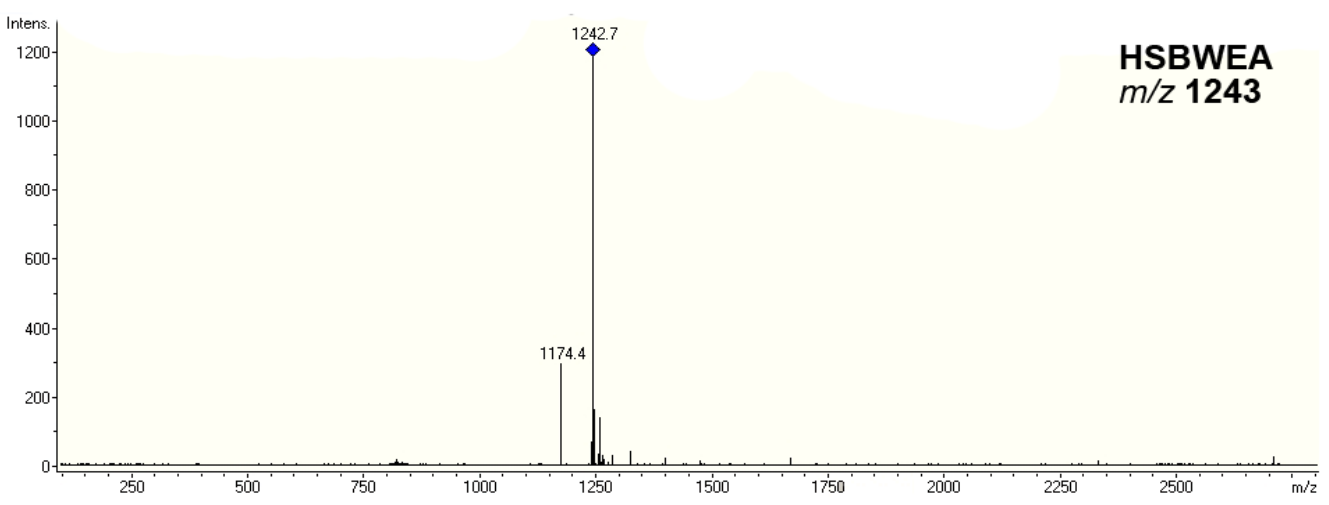

Figure 9. The fragmentation pattern of HSBWEA fraction 19 at (A) $\mathrm{m} / \mathrm{z} 1227$ and (B) $\mathrm{m} / \mathrm{z}$ 1243 analyzed by LC/MS/MS

Table 1. The molecular masses of HSBWEA fraction 19 by LC-MS/MS with corresponding compounds from related sea cucumbers.

\begin{tabular}{|c|c|c|c|c|}
\hline$m / z$ & Intensity & $\begin{array}{l}\text { Fragmented } \\
\text { molecules }\end{array}$ & Name of corresponding compounds & References \\
\hline 507 & $3.5 \times 10^{5}$ & 493.9 & $\begin{array}{l}\text { Key molecule of Saponin (sodiated aglycone } \\
\text { moiety), M1 fraction (Athyonidium chilensis) }\end{array}$ & {$[15,16]$} \\
\hline \multirow{2}{*}{764} & \multirow{2}{*}{$3.0 \times 10^{4}$} & \multirow{2}{*}{$605,611,720$} & Holothurinoside D (H. forskali) & {$[17]$} \\
\hline & & & M2 fraction (Athyonidium chilensis) & {$[16]$} \\
\hline 1014 & $1.0 \times 10^{4}$ & $373,451,703.6$ & M3 fraction (A. chilensis) & {$[16]$} \\
\hline 1227 & $1.5 \times 10^{4}$ & $\begin{array}{l}743, \underline{931}, \underline{1107} \\
1158\end{array}$ & Scabraside A (H. scabra) & {$[11,15]$} \\
\hline 1243 & $0.4 \times 10^{4}$ & $\underline{593.2}, \underline{1106.6}$ & $\begin{array}{l}\text { Holothurin A, Scabraside B (H. scabra, H. } \\
\text { lessoni, H. fuscocinerea, H. impatients) }\end{array}$ & {$[11,15,18]$} \\
\hline 1259 & $0.3 \times 10^{4}$ & $960.8,1070.6$ & Holothurin A3 (H. scabra) & {$[10,15]$} \\
\hline \multirow{2}{*}{1302} & \multirow{2}{*}{$0.2 \times 10^{4}$} & \multirow{2}{*}{$\begin{array}{l}747.1,1233.7 \\
1359.8,1368.8\end{array}$} & Holothurin A (H. scabra) & {$[18]$} \\
\hline & & & Holothurinoside M (H. lessoni) & {$[15]$} \\
\hline 1392 & $0.7 \times 10^{3}$ & $1255.2,1327.2$ & Holotoxin A1 (Apostichopus japonicus) & {$[19,20]$} \\
\hline 1522 & $2.0 \times 10^{4}$ & $\begin{array}{l}653,845,1077 \\
1289\end{array}$ & M5 fraction (A. chilensis) & {$[16]$} \\
\hline
\end{tabular}

: identical fragmented $\mathrm{m} / \mathrm{z}$ to that species 


\section{DISCUSSION}

Sea cucumbers have been used as foods and Asiatic folk medicines with numerous therapeutic applications. Triterpene glycosides are the major bioactive compounds isolated from the body wall, viscera as well as the cuvierian tubules of sea cucumbers [9, 21]. These extracts contained abundant triterpene glycosides that possess potent cytotoxic property [9]. In $H$. scabra, the body wall is the most suitable source that yields the highest amount of triterpene glycosides as this species does not have the cuvierian tubules [22]. In this study, we selected the ethyl acetate fraction of the extract as it contained the highest amount of triterpene glycosides for evaluating their effects against human GBM cell lines.

HSBWEA contained various compounds whose mass spectra corresponded with various triterpene glycosides that have been identified in other sea cucumbers. Specifically, HSBWEA contained triterpene glycosides as previously described in $H$. scabra, including scabraside A, scabraside B, and holothurin A3 [10, 11]. Holothurin A3 has strong cytotoxic effect against KB human epidermal and HepG2 hepatocellular carcinomas [10]; however, anticancer effect of scabraside A and B have not yet been investigated. Starfish's triterpene glycosides have been shown to possess in vitro anti-GBM activity [14], while the effects of sea cucumbers triterpene glycosides on GBM have not yet been investigated. Our studies indicated that HSBWEA induced cytotoxic against both human GBM cells in dose- and timedependent manners with low $\mathrm{IC}_{50}$ value, which was more cytotoxic than $\mathrm{TMZ}$, a primarily palliative drug used for GBM treatment in the patients. This difference might be due to the chemoresistance effect of these cell lines to TMZ as previously reported [23, 24]. In comparison, HSBWEA did not exhibited toxicity in primary human fetal astrocytes (HFA) at sub-cytotoxic as well as cytotoxic concentrations (between $0.1-5 \mu \mathrm{g} / \mathrm{ml}$ ), but was toxic at high concentration $(10-100 \mu \mathrm{g} / \mathrm{ml})$. This could be due to the general membranolytic activity of triterpene glycosides at very high concentration.

Triterpene glycosides may exercise anticancer activity against various cancers through different mechanisms of action, including apoptosis induction, autophagy activation, and metastatic inhibition [8]. The holothurian triterpene glycosides have membranolytic ability to rupture cell membrane and increase permeability, which causes hemolytic, cytotoxic as well as cell death actions $[12,25]$. Apoptosis induction in cancer cells is characterized by three stages of cellular changes. The early stage is the loss of mitochondrial membrane permeability. The mid stage involves the translocation of phosphatidyl serine from the inner to the outer surfaces of the cell membrane. The late stage is indicated by the changes of nuclear morphological features, including chromatin condensation and nuclear fragmentation [26]. Detection of apoptotic cells after HSBWEA treatment by the Annexin V/PI assay showed significant enhancement of the early-to-mid stage apoptotic cells at low dose while more of the late stage apoptotic cells appeared at high dose. This result suggested that HSBWEA exerted its action through three steps of apoptotic changes that eventually lead to marked morphological changes of the targeted cells, including the rounding up of the cytoplasm, the shortening of the cellular processes, the shrinkage and detachment from the substrate, and the decreased confluence of the cell [27].

Mitochondria and nuclei are the major targeted organelles that are affected by apoptosis. HSBWEA treatment caused the loss of mitochondrial transmembrane potentials $(\Delta \Psi \mathrm{m})$ in GBM cells, initiating the release of cytochrome $\mathrm{c}$ and subsequent activation of downstream apoptotic molecules in the cascade of the intrinsic apoptotic pathway [28]. The ensuing morphological changes in the nucleus of apoptotic GBM cells could be resulted from the 
cleavage of several mitotic proteins and DNA by activated caspases during the late stage of apoptosis, leading to the condensation and fragmentation of chromatin and eventually the loss of nuclear integrity and function [26, 29]. This confirmed that the HSBWEA extract could induce apoptosis in the GBM cells up to the last stage.

At the upstream of the intrinsic apoptotic pathway, the mitochondrial membrane damage lead to expression and release of pro-apoptotic factors from mitochondria into cytosol that subsequently activate the downstream caspases, including the executional caspase-3 [30]. This process is regulated by the balance between the expression of the pro- and anti-apoptotic molecules, Bax and Bcl-2, respectively [31]. Thus, the expression levels of Bax, Bcl-2 and caspase-3 are considered hallmarks of the efficacy of anticancer agents [30, 32, 33]. HSBWEA-treated GBM cells exhibited increased the expressions of the pro-apoptotic Bax and effector caspase-3 with the decreased expression of the anti-apoptotic Bcl-2. The $\mathrm{Bax} / \mathrm{Bcl}-2$ ratio was proportionally increased in a concentration-dependent manner. The molecular indices implicated that HSBWEA promoted apoptosis in GBM cells through the intrinsic pathway. In addition, triterpene glycosides could interact with cholesterol-rich membranes leading to membrane instability and breakage, which can also lead to apoptotic and non-apoptotic cell death $[8,34,35]$.

\section{CONCLUSION}

HSBWEA contains complex of triterpene glycosides as the main bioactive ingredients that inhibit growth of human GBM cells. The apoptosis inducing effect of HSBWEA was characterized by a significant activation of pro-apoptotic molecules of the intrinsic pathway. Other in vitro effects such as on autophagy as well as in vivo effect of the extract need further investigation to establish whether the compounds in this extract can be considered a new chemotherapeutic agent for human GBM.

Abbreviations: GBM: glioblastoma; HSBWEA: the ethyl acetate solvent extracts from body wall of H. scabra; MEM: minimal essential media; DMEM: Dulbecco's modified eagle media; $\Delta \Psi \mathrm{m}$ : mitochondrial transmembrane potentials

Competing Interests: The authors have no conflicts of interest.

Authors' Contributions: All authors contributed to this study

Acknowledgements and funding: This work is financially supported by the grants from Agricultural Research Development Agency (Public Organization), Thailand to Prof.Prasert Sobhon, and the National Research Council of Thailand to Kant Sangpairoj.

\section{REFERENCES}

1. Rock K, McArdle O, Forde P, Dunne M, Fitzpatrick D, O'Neill B, et al. A clinical review of treatment outcomes in glioblastoma multiforme--the validation in a nontrial population of the results of a randomised Phase III clinical trial: has a more radical approach improved survival? Br J Radiol 2012; 85(1017):e729-33.

2. Kortmann RD, Jeremic B, Weller M, Plasswilm L, Bamberg M. Radiochemotherapy of malignant glioma in adults. Clinical experiences. Strahlenther Onkol 2003;179(4):219-32. 
3. Hamel JF, Conand C, Pawson DL, Mercier A. The sea cucumber Holothuria scabra (Holothuroidea : Echinodermata): Its biology and exploitation as beche-de-mer. Adv Mar Biol 2001;41:129-223.

4. Bordbar S, Anwar F, Saari N. High-value components and bioactives from sea cucumbers for functional foods--a review. Mar Drugs 2011;9(10):1761-805.

5. Janakiram NB, Mohammed A, Rao CV. Sea Cucumbers Metabolites as Potent AntiCancer Agents. Mar Drugs 2015;13(5):2909-23.

6. Omran NE, Khedr AM. Structure elucidation, protein profile and the antitumor effect of the biological active substance extracted from sea cucumber Holothuria polii. Toxicol Ind Health 2015;31(1):1-8.

7. Kim SK, Himaya SW. Triterpene glycosides from sea cucumbers and their biological activities. Adv Food Nutr Res 2012;65:297-319.

8. Podolak I, Galanty A, Sobolewska D. Saponins as cytotoxic agents: a review. Phytochem Rev 2010;9(3):425-74.

9. Li YX, Himaya SW, Kim SK. Triterpenoids of marine origin as anti-cancer agents. Molecules 2013;18(7):7886-909.

10. Dang NH, Thanh NV, Kiem PV, Huong le M, Minh CV, Kim YH. Two new triterpene glycosides from the Vietnamese sea cucumber Holothuria scabra. Arch Pharm Res 2007;30(11):1387-91.

11. Han H, Yi Y, Xu Q, La M, Zhang H. Two new cytotoxic triterpene glycosides from the sea cucumber Holothuria scabra. Planta Med 2009 Dec;75(15):1608-12.

12. Wang J, Han H, Chen X, Yi Y, Sun H. Cytotoxic and apoptosis-inducing activity of triterpene glycosides from Holothuria scabra and Cucumaria frondosa against HepG2 cells. Mar Drugs 2014;12(8):4274-90.

13. Yu S, Ye X, Huang H, Peng R, Su Z, Lian XY, et al. Bioactive sulfated saponins from sea cucumber Holothuria moebii. Planta Med 2015;81(2):152-9.

14. Tian X, Tang H, Lin H, Cheng G, Wang S, Zhang X. Saponins: the potential chemotherapeutic agents in pursuing new anti-glioblastoma drugs. Mini Rev Med Chem 2013;13(12):1709-24.

15. Bahrami Y, Zhang W, Chataway T, Franco C. Structure elucidation of five novel isomeric saponins from the viscera of the sea cucumber Holothuria lessoni. Mar Drugs 2014;12(8):4439-73.

16. Sottorff I, Aballay A, Hernández V, Roa L, Muñoz L, Silva M, et al. Characterization of bioactive molecules isolated from sea cucumber Athyonidium chilensis. Revista de Biología Marina y Oceanografía 2013;48(1):23-35.

17. Rodriguez J, Castro R, Riguera R. Holothurinosides: new antitumour non sulphated triterpenoid glycosides from the sea cucumber Holothuria forskali. Tetrahedron 1991(47):4753-62.

18. Bondoc KG, Lee H, Cruz LJ, Lebrilla CB, Juinio-Menez MA. Chemical fingerprinting and phylogenetic mapping of saponin congeners from three tropical holothurian sea cucumbers. Comp Biochem Physiol B Biochem Mol Biol 2013;166(3-4):182-93.

19. Kalinin VI, Prokofieva NG, Likhatskaya GN, Schentsova EB, Agafonova IG, Avilov SA, et al. Hemolytic activities of triterpene glycosides from the holothurian order Dendrochirotida: some trends in the evolution of this group of toxins. Toxicon 1996;34(4):475-83. 
20. Yang J, Wang Y, Zhang R, Jiang T, Lv Z. Determination of the triterpene glycosides in sea cucumbers by liquid chromatography with evaporative light scattering and mass spectrometry detection. J Sep Sci 2015;38(7):1117-22.

21. Van Dyck S, Gerbaux P, Flammang P. Qualitative and quantitative saponin contents in five sea cucumbers from the Indian ocean. Mar Drugs 2010;8(1):173-89.

22. Dabbagh A-R, Keshavarz M, Mohammadikia D, Afkhami M, Nateghi SA. Holothuria scabra (Holothuroidea: Aspidochirotida): first record of a highly valued sea cucumber, in the Persian Gulf, Iran. Marine Biodiversity Records 2012;5:1-6.

23. Chamberlain MC. Temozolomide: therapeutic limitations in the treatment of adult high-grade gliomas. Expert Rev Neurother 2010;10(10):1537-44.

24. Yoshino A, Ogino A, Yachi K, Ohta T, Fukushima T, Watanabe T, et al. Gene expression profiling predicts response to temozolomide in malignant gliomas. Int $\mathrm{J}$ Oncol 2010;36(6):1367-77.

25. Aminin DL, Menchinskaya ES, Pisliagin EA, Silchenko AS, Avilov SA, Kalinin VI. Anticancer activity of sea cucumber triterpene glycosides. Mar Drugs 2015;13(3):1202-23.

26. Ziegler U, Groscurth P. Morphological features of cell death. News Physiol Sci 2004;19:124-8.

27. Kepp O, Galluzzi L, Lipinski M, Yuan J, Kroemer G. Cell death assays for drug discovery. Nat Rev Drug Discov 2011;10(3):221-37.

28. Kroemer G, Galluzzi L, Brenner C. Mitochondrial membrane permeabilization in cell death. Physiol Rev 2007;87(1):99-163.

29. Martelli AM, Zweyer M, Ochs RL, Tazzari PL, Tabellini G, Narducci P, et al. Nuclear apoptotic changes: an overview. J Cell Biochem 2001;82(4):634-46.

30. Reed JC. Mechanisms of apoptosis. Am J Pathol 2000;157(5):1415-30.

31. Kuwana T, Newmeyer DD. Bcl-2-family proteins and the role of mitochondria in apoptosis. Curr Opin Cell Biol 2003;15(6):691-9.

32. Rovini A, Savry A, Braguer D, Carre M. Microtubule-targeted agents: when mitochondria become essential to chemotherapy. Biochim Biophys Acta 2011;1807(6):679-88.

33. Fulda S, Debatin KM. Extrinsic versus intrinsic apoptosis pathways in anticancer chemotherapy. Oncogene 2006;25(34):4798-811.

34. Francis G, Kerem Z, Makkar HP, Becker K. The biological action of saponins in animal systems: a review. Br J Nutr 2002;88(6):587-605.

35. Melzig MF, Bader G, Loose R. Investigations of the mechanism of membrane activity of selected triterpenoid saponins. Planta Med 2001;67(1):43-8. 